\title{
HIGH-TEMPERATURE ESTIMATION OF ENERGY ACCOMMODATION COEFFICIENT OF GAS MOLECULES ON THE SURFACE
}

\author{
I. S. Altman \\ Institute of Combustion $6 \%$ Advanced Technologies, \\ Odesa State University, \\ 2 Dvorians'ka Str., Odesa, UA-65026, Ukraine \\ (Received September 24, 1999)
}

\begin{abstract}
The upper estimation of energy accommodation coefficient is obtained. It is shown that this coefficient tends to zero asymptotically for high temperatures. It means that at high temperatures the efficiency of heat transfer between gas and condensed body is small when gas-surface collisions occur in free-molecular regime

Key words: accommodation coefficient, gas-surface collisions.
\end{abstract}

PACS number(s): 44.30.+v

The heat transfer between gas and a condensed body in free-molecular regime of gas-surface collisions can be described with using the energy accommodation coefficient (EAC). EAC is defined as the ratio of the average energy $\overline{\Delta E}$ which transfers during the collision of a gas molecule with the surface to the energy transferred by full accommodation [1,2]:

$$
\alpha_{E}=\frac{\overline{\Delta E}}{\left(\frac{C_{V}}{R}+\frac{1}{2}\right) k_{B}\left(T_{g}-T_{s}\right)},
$$

where $C_{V}$ is the molar gas capacity, $R$ is the gas constant, $k_{B}$ is the Boltzmann constant, $T_{g}, T_{s}$ are the temperatures of gas and the condensed body accordingly.

The objective of the present work lies in obtaining the upper high-temperature estimation of EAC. This estimation may be important for the description of heat transfer in plasma with condensed phase if the value of EAC is sufficiently small. In this case the conductive heat transfer between nanoparticles and gas can be ignored and the condensed particles would be thermally isolated from the gas. Such a situation is realized apparently during gas-phase combustion of metals when the energy evolved during condensation of the gaseous oxide molecules is the cause of the oxide particles superheat [3]. Moreover, in this case unlike the conductive heat transfer the radiation becomes the main channel of the removal of the condensation energy [4].

In accordance with $[1,2]$ the average energy transferred during a single collision between a gas molecule and the surface can be written as

$$
\begin{gathered}
\overline{\Delta E}=\sum_{\alpha} \sum_{E} \epsilon_{\alpha}\left[f\left(E+\epsilon_{\alpha}\right) \omega_{\alpha}^{+}\left(E+\epsilon_{\alpha}, E\right)-\right. \\
\left.f(E) \omega_{\alpha}\left(E, E+\epsilon_{\alpha}\right)\right]
\end{gathered}
$$

where $f(E)$ is the function which describes the equilibrium distribution of gas molecules colliding with the surface, $\omega_{\alpha}^{+}\left(E_{1}, E_{2}\right), \omega_{\alpha}\left(E_{1}, E_{2}\right)$ are the probabilities of a gas molecule transition from the state with the energy $E_{1}$ to the state with the energy $E_{2}$ which are accompanied by the creation or annihilation of the phonon of $\alpha$-type with energy $\epsilon_{\alpha}$ in the condensed body.

The main difficulties of the calculation of EAC is connected with the probabilities $\omega_{\alpha}^{+}$and $\omega_{\alpha}$ modelling. However, these probabilities must always satisfy the following equation

$$
\frac{\omega_{\alpha}^{+}\left(E_{1}, E_{2}\right)}{\omega_{\alpha}\left(E_{2}, E_{1}\right)}=\frac{N_{\alpha}+1}{N_{\alpha}}=\exp \left(\frac{\epsilon_{\alpha}}{k_{B} T_{s}}\right),
$$

where $N_{\alpha}$ is the equilibrium number of $\alpha$-type phonons. According to the detailed balancing principle the expression in square brackets in Eq. (2) turns to zero if the temperatures of gas and the condensed body are equal. Thus

$$
f(E)=\text { const } \exp \left(-\frac{E}{k_{B} T_{g}}\right)
$$

For the gas molecule collision with the surface considered above the total probability of elastic and inelastic interaction obviously equals unity. That is why the probability of inelastic interaction occurs:

$$
\Gamma \equiv \sum_{\alpha} \sum_{E}\left[f\left(E+\epsilon_{\alpha}\right) \omega_{\alpha}^{+}\left(E+\epsilon_{\alpha}, E\right)+f(E) \omega_{\alpha}\left(E, E+\epsilon_{\alpha}\right)\right] \leq 1
$$

Dividing Eq. (2) on Eq. (5) we obtain 


$$
\overline{\Delta E} \leq \frac{\sum_{\alpha} \sum_{E} \epsilon_{\alpha}\left[f\left(E+\epsilon_{\alpha}\right) \omega_{\alpha}^{+}\left(E+\epsilon_{\alpha}, E\right)-f(E) \omega_{\alpha}\left(E, E+\epsilon_{\alpha}\right)\right]}{\sum_{\alpha} \sum_{E}\left[f\left(E+\epsilon_{\alpha}\right) \omega_{\alpha}^{+}\left(E+\epsilon_{\alpha}, E\right)+f(E) \omega_{\alpha}\left(E, E+\epsilon_{\alpha}\right)\right]} .
$$

The estimation Eq. (6) for $\overline{\Delta E}$ can be majorized by the expression

$$
\max _{E, \epsilon_{\alpha}}\left\{\frac{\epsilon_{\alpha}\left[f\left(E+\epsilon_{\alpha}\right) \omega_{\alpha}^{+}\left(E+\epsilon_{\alpha}, E\right)-f(E) \omega_{\alpha}\left(E, E+\epsilon_{\alpha}\right)\right]}{\left[f\left(E+\epsilon_{\alpha}\right) \omega_{\alpha}^{+}\left(E+\epsilon_{\alpha}, E\right)+f(E) \omega_{\alpha}\left(E, E+\epsilon_{\alpha}\right)\right]}\right\} .
$$

The latter one with the help of Eq. (3) and Eq. (4) can be reduced to the form

$$
\max _{\epsilon_{\alpha}}\left\{\epsilon_{\alpha} \tanh \left[\frac{\epsilon_{\alpha}}{2 k_{B}}\left(\frac{1}{T_{s}}-\frac{1}{T_{g}}\right)\right]\right\} .
$$

The expression under the maximum designation is the monotonous function of $\epsilon_{\alpha}$. Thus the upper estimation of EAC can be written as

$$
\alpha_{E} \leq \frac{\Theta \tanh \left[\frac{\Theta}{2}\left(\frac{1}{T_{s}}-\frac{1}{T_{g}}\right)\right]}{\left(\frac{C_{V}}{R}+\frac{1}{2}\right)\left(T_{g}-T_{s}\right)}<\frac{1}{\left(2 \frac{C_{V}}{R}+1\right)} \frac{\Theta^{2}}{T_{g} T_{s}}
$$

where $\Theta$ is the Debye temperature which corresponds to the limit energy of the condensed body phonons.

The numerical calculation shows that for the typical temperatures in the plasma with the condensed phase $T_{g}, T_{s} \sim 3000 \mathrm{~K}$ and for $\Theta \sim 300 \mathrm{~K} \alpha_{E} \sim 1 / 400$ (monatomic gas) and $\alpha_{E} \sim 1 / 600$ (diatomic gas).

The obtained result of the zero high-temperature limit of EAC seems to be general. It should be taken into account by theoretical description of heat transfer between the gas and condensed particles

The author is grateful to F. O. Godman for stimulating discussions.

The work was partially supported by INTAS (grant 96-2334).
[1] F. O. Goodman, H. Y. Wachman, Dynamics of GasSurface Scattering (Academic Press, New York, 1976).

[2] S. F. Borisov, N. Ph. Balakhonov, V. A. Gubanov, Vzaimodieistviie gaza s povierkhnost'yu tviordykh tel (Gas Interaction with Surface of Solid Body) (Nauka, Moscow,
1988)

[3] A. V. Krestinin, V. A. Kuznetsov, Khim. Fiz. 5, 403 (1986).

[4] I. S. Altman, Fiz. Goreniia i Vzryva 34, No. 4, 49 (1998).

\title{
ВИСОКОТЕМПЕРАТУРНА ПОВЕДІНКА КОЕФЩІЕНТА АКОМОДАЦЇ̈ ЕНЕРІІЇ ГАЗОВИХ МОЛЕКУЛ НА ПОВЕРХНІ
}

\author{
I. С. Альтман \\ Інститут горіння та нетрадиційних технологій, \\ Одесъкий держсавний університет ім. Мечнікова, \\ вул. Дборянсвка, 2, Одеса, 65026, Украӥна \\ E-mail: ialtman@tm.odessa.ua
}

Отримано верхню оџінку коефіпієнта акомодапії енергії. Показано, що цей коефіџієнт при високих температурах має нульову асимптотику. Це означає, що при високих температурах ефективність теплообміну між газом та конденсованим тілом є малою, коли зіткнення газових молекул з поверхнею здійснюються у вільно-молекулярному режимі. 